\title{
Accounting for the male domination through legislative empowerment of upper-middle class women in the early $19^{\text {th }}$ century Spain
}

\author{
Maria Delores Capelo Bernal \\ Pedro Arujo Pinzon \\ Warwick Funnell
}




\section{Accounting for the male domination through legislative empowerment of upper-middle class women in the early $19^{\text {th }}$ century Spain}

\section{Introduction}

Numerous studies have shown accounting to be an instrument of male domination of women in the public sphere, mainly in Anglo-Saxon professional settings (highlighted by Carrera et al, 2001; Cooper, 2001; Kirkham and Loft, 2001; Komori, 2008). Increasingly, researchers have also exposed the use of accounting practices to reproduce gender inequality in the private domestic arena (see Komori, 2012). Accounting in the private domestic arena has been shown not only to reflect social and cultural prescriptions but also to support the existing social order by reinforcing power relationships between men and women (Walker, 1998; Ezzamel, 2002a) as one of the "less overt techniques" of male domination (Walker, 2008 , p. 591). In contrast, other studies have suggested that accounting has the potential to be a source of power for women when managing their households (Kirkham and Loft, 2001; Komori and Humphrey, 2000; Komori, 2012). This enabling power of everyday household accounting, until the present study, has not considered the implications when a woman has a legal entitlement to properties after marriage (Walker, 1998; Komori, 2007).

Social feminist theory emphasizes the importance of socialisation processes and posits that there are differences 'between males' and females' experiences from the earliest moments of life that result in fundamentally different ways of viewing the world" (Fischer et al., 1993, p. 154). Families and the home are particularly relevant sites to analyse the continued reproduction of gender inequalities, showing the relationship between patriarchy and capitalism (Calás and Smircich, 2006). In addition, examination of the household throughout history in different places provides a powerful means to observe the contribution of accounting in constructing, mediating and sustaining power relations between males and females (Walker, 2008), but especially in patriarchal societies where women are dominated by men in all aspects of their lives. Therefore, further research is needed to shed light on the relationship between accounting and gendered spaces (Carmona and Ezzamel, 2016) in a variety of socio-cultural contexts (Komori, 2008), thereby recognising that women are not "a unitary, homogeneous category" (Fearfull and Kamenou, 2006, p. 884).

This study provides the opportunity for 'voices from below' to be heard (Napier, 2006, p. 459), to address both the neglect of non Anglo-centric accounting gendered practices beyond the predominant professional setting and the controversial roles of women and accounting in power relationships inside the household. It focuses on the reciprocal interaction of accounting with practices and processes of daily life (Hopwood, 1994; Jeacle, 2009; Jackson et al, 2012; Carmona and Ezzamel, 2016) in a rigid patriarchal socio-cultural and juridical context by answering four research questions: how did accounting for women's property rights help to enforce their male domination; how did women perceive accounting in this context of male domination; was accounting a male/female technology in the household and how was accounting for shielding women in action?

The subject of the present study is a Spanish upper-middle-class Catholic family in the early $19^{\text {th }}$ century, the Langton-Dillóns, who lived in Cádiz and belonged to an Irish dynasty 
which took up residence in Spain from the early $18^{\text {th }}$ century. The family enjoyed the profits from an overseas business for more than 40 years during the "Golden Century" (GarcíaBaquero, 1972) of Cádiz which was the main port at the time for European trade with the Spanish colonies in America. This importance as a port meant that Cádiz was a place where state-of-the-art commercial and accounting practices could be acquired (Capelo, Araújo and Álvarez-Dardet, 2005). Examination is mainly focused on the period when the family's socioeconomic status was seriously threatened because of the War of Independence between Spain and France (1808-1814).

There are a number of contributions of this study. Firstly, it recognizes accounting as a social practice present in the diversity of daily routines experienced by people who inhabit different spatial and historical settings, and the role of accounting in shaping the lived experience of men and women (see Carmona and Ezzamel, 2016), most especially at times of major transition in a woman's life and those of their relatives. The research highlights through actual practices the potential of household accounting to reflect and reinforce a private patriarchy, thereby reaffirming existing gender divisions, at a time when it was usual for women to have little economic power. In particular, this research shows the impact of differences between the legal prescriptions of Anglo-Saxon countries and Spain during the early $19^{\text {th }}$ century. Contrasting with the Anglo-Saxon contemporary context, in the period studied the Spanish law preserved a woman's property rights, guaranteeing recovery of properties owned by her before marriage should the marriage break up and be legally annulled or the marriage was dissolved upon the death of the husband. In this context, women had a presence in household accounting as a creditor or debtor, in a similar manner as men. Although women were not necessarily economically defenceless, mostly they played a limited role in accounting which was centered mainly on providing expenses receipts. Accounting practices of men contributed to maintaining and legitimizing the social order where women were subjugated by males. Men controlled properties and exerted a protective role over women who were confined to the household where they exerted a stewardship role.

The structure of the paper is as follows. Firstly introduced are the theoretical insights and methods used to understand the cultural and legal setting, as well as the implications of accounting practices in the early $19^{\text {th }}$ century Spain in relation to both the property rights of married women and their households. This is followed by a brief history of the LangtonDillón family and its move from Spain to England, which identifies the attitudes and responsibilities of the Langton males towards women at this time of great upheaval and uncertainty in the family. Next the paper provides the evidence obtained about gender and accounting in the private domestic arena. Finally, the conclusions are presented.

\section{Feminist social theory in context}

There is not one overarching theory capable of explaining gender divisions everywhere (Thane, 1992). Thus, different theoretical perspectives help to explain gender differences (Calás and Smircich, 2006; Haynes, 2008). This study gives particular emphasis to the perspective of feminist social theory which considers that women and men are subjected to socialization processes throughout their lives that result in different ways of viewing the world and in them behaving differently (Fischer et al., 1993). This perspective argues that gender differences are socially constructed and affect women's and men's perceptions and decisions, but also through the micro-processes that constitute social structures (Calás and Smircich, 2006) such as those occurring between individuals inside families. 
Gender(ing) is a continuous process which is performed in everyday practice through the daily construction of gender identity. Gender behavior reflects the particular contexts in which it is developed, rather than there being a universal identity for a woman or a man, although there may be common features (Haynes, 2008). Gender identity is transformed into the everyday life of women and men in a space that matters, a space that is not neutral and that is the materialization of the socio-cultural norms that affect gender performance (Tyler and Cohen, 2010; Panayiotou, 2015). According to Tyler and Cohen (2010, p. 195), space matters "both in terms of its meaning, and also in the sense that it continues to embody -to materialize- socially significant aspects of identity, of social interaction and, perhaps most notably, of power relations". In all time periods, these rules and power relations are expressions of specific historical developments. Thus, to understand the meaning of space and how it materializes these rules and relationships it is first necessary to understand its specific social, political and cultural context.

In context of the early $19^{\text {th }}$ century western Europe the house was a space for confining women, a place where they were separated from the public sphere and the workplace, which were reserved for men. In the Ancien Régime, women in Spain were forced to obey and to be legally and economically dependent on men. The figure of La Perfecta Casada (The Perfect Wife) in the seventeenth century, as exemplified in the work of Fray Luis de León (1583) where he claimed that a woman should serve her husband, raise children, do domestic tasks, be hardworking and spend less, indicates the expectations of the rigid patriarchal Spanish society. Although the situation changed later, the archetype of woman as the "Angel of the Home" was maintained in the new social model of the $19^{\text {th }}$ century for the bourgeois woman, for whom the house was to be her ideal space where she worked to protect the family as the main part of society (Cantero, 2007). The Enlightenment fostered the concept of the immediate family which "consolidated itself within the interior of the great traditional familyas-alliance" (Foucault, 1980, p. 173). Concerns about the well-being of the population were increasingly used to justify governmental intervention in the lives of families, the king's authority in Spain being reaffirmed through the father's role as the source of authority. More than ever, the family became the main element for both social and political organization. Especially important in this sense was Antonio Arbiol's work, La familia regulada (The ruled family), which was reprinted more than twenty times after the first edition in 1704. In this book the author rendered the Catholic doctrine regarding the family, considering it as a hierarchical institution overseen by the father and husband and where unequal relationships took place (Irigoyen, 2011).

\section{Accounting for gender}

Accounting is not gender neutral but instead is both gendered and gendering (Carmona and Ezzamel, 2016). Studies by Komori (2008, 2012), Lehman (2012) and Carmona and Ezzamel (2016) provide useful insights about the current state of accounting research on gender and the need to deepen further our understanding of the interrelationship between accounting and gender. More specifically, until recently, the literature on accounting and gender has mainly focused on professional accounting occupations in predominantly AngloSaxon settings. Research has shown that particular occupations and practices may have gendered identities that can change over time and across different contexts (Kirkham and Loft, 1993; Robert and Coutts, 1992). It has also been suggested that accounting can be a means of building a (non)gendered world (Parker, 2008). Several factors have been 
highlighted as reinforcing gender practices affecting the advancement of a woman's career in accounting, including: cultural values regarding the expected family roles of men and women (Anderson-Gough et al, 2005); stereotyping (Ciancanelli et al, 1990; Kim, 2004; Komori, 2008; Duff, 2011); dominant language and discourses (Cooper, 1992, 2001; Kim, 2008; Dambrin and Lambert, 2012); government regimes and religion (Carrera et al, 2001); and class, race and other specific circumstances of the women studied (Hammond and Oakes, 1992; Hammond, 1997; Gallhofer, 1998; Kim, 2004; Fearfull and Kamenou, 2006). Amidst this research, accounting remains under-researched as a gendering practice.

Hines (1992) and Dillard and Reynolds (2008) suggest that the potential of accounting for perpetuating gender inequality comes especially from its ability to perceive and communicate the world through a masculine lens, showing the world as rational, logical and analyzable in a cold framework. In contrast, it is suggested that the presence of a more feminine perspective could promote a more informal and closer process of accountability (Oakes and Young, 2008), at the same time allowing women a successful experience in the accounting profession (Komori, 2008). Reflecting the present stereotypes or prejudices regarding the capabilities of women, "rather than being a professional accountant, society expects women to be the 'household accountant', and/or the wife attentive and understanding spouse of the chartered accountant" (Dambrin y Lambert, 2012, p. 8). However, the role of women in household accounting has not been always the same either over time or in different contexts.

Throughout studies of the home, gender has been shown to be a major factor linked to domestic accounting. Numerous studies have provided historical evidence, predominantly based on instructional texts, books and other secondary sources, of women's subjugation through the application of accounting technologies focused on restraining extravagant expenditure and/or confining women to the home (Walker, 1998, 2003; Komori, 2007; Walker and Carnegie, 2007). The literature also recognises cases in which accounting did not contribute to the domination of women but instead was the means to empower them (Carnegie and Walker, 2007a, 2007b; Komori and Humphrey, 2000; Kirkham and Loft, 2001; Komori, 2007, 2012). Regardless of gender, studies have also identified the relevance of household accounting at critical junctures in an individual's life, such as marriage, the birth of children, death and the impact of financial constraints on the family economy (Walker and Llewellyn, 2000).

Social feminist theory recognizes the relationships between patriarchy and capitalism. In a patriarchal context, the centralization of household money management under the control of the male would imply power differentials in decision-making with respect to the household's resources and, subsequently, potentially differences in living standards of the husband and wife. These latter differences are especially evident in those households where males manage and control the money through the housekeeping allowance system whereby husbands give their wives a fixed sum for housekeeping expenses and retain control of the remaining money (Vogler and Pahl, 1994). This not only confers great power on the male but also allows the opportunity for the male to engage in activities denied dependent women. Accordingly, the role of household budgeting and the associated accounting are critical for the allocation of family expenditure by which male priorities can be introduced and given pre-eminence and, thereby, provide the potential to enshrine and perpetuate inequalities of gender to reinforce existing domestic power relations (Walker and Llewellyn, 2000; Walker and Carnegie, 2007).

Studies of household accounting and gender have focused mainly on Britain, USA, Australia and Japan across different periods. They have shown that patriarchal ideologies are not universal (Calás and Smircich, 2006) and that both patriarchal ideologies and their 
practices differ over time and place, adapting to economic, social, political and cultural changes (Walker, 2003). However, the existing literature has not yet considered the potential of accounting in a patriarchal context where married women preserved their economic rights, such as Castilian women at the end of the Ancien Régime. The study of this specific context of male domination will provide the means to establish whether accounting contributed to enforce or weaken the private patriarchy in an environment where women had major opportunities to access and control economic resources.

\section{Methodology}

This work utilizes a qualitative research methodology based both on a historical interpretative perspective, sensitive to the context (Merino and Mayper, 1993), and on a longitudinal case study of a family to examine the role of accounting in the everyday lived experiences of women and men (Carmona and Ezzamel, 2016) and, hence, to "make visible the informal and invisible processes of segregation" (Calás and Smircich, 2006, p. 305). Recognising that "women" is not a homogeneous category (Hammond and Preston, 1992), the Langton-Dillón family is viewed as an outstanding example of the Spanish upper-middleclass at the time whose women had economic and property rights which were in direct contrast with those of women in the poorest classes. These unusual property rights required that the women had access to notarial and accounting information to verify and protect this patrimony (Ortego, 1999).

Several archives have been consulted including, in Spain, the Archivo Histórico Provincial de Cádiz (AHPC) which contains a particularly important document, the will of the head of the Langton-Dillón family, Miguel Langton Careu (hereafter MLC). The primary sources used date from 1809 onwards, although they contain information referring to the entire period which is the concern of this work. In England the Bath Record Office (BRO) has preserved documents of the Langton-Dillón family and correspondence between male members of the family, both personal and business related. The large number of letters which have survived has facilitated an in-depth study of the people who were affected by accounting calculations, thereby reinforcing the microhistorical character of the study (Carnegie and Walker, 2007b). Moreover, these same records have made it possible to know who collaborated in family accounting and the purposes for which it was used. The Worcester Record Office (WRO) in England also contains relevant notarial documents, with a solid accounting basis, related to the distribution of MLC's inheritance. Accounting was a prominent daily activity in the household with which the women developed strategies to defend their economic interests (Fernández, 1997a). Accounting was very important both for the family's business, especially for the head of the family who was proud of his honesty in business, and for family life. Primary evidence such as correspondence (Vickery, 2006), together with notarial and accounting documents, and most especially wills of deceased males, provides the means to hear the voices of the women to gain access to their true feelings and perceptions regarding male domination and the role of accounting in perpetuating and challenging this dominance (Hanna, 2003).

The period investigated begins when Miguel Langton Careu married María Dillón in 1766. After more than 40 years of partnership, during which they enjoyed the profits from MLC's business, the family entered a critical period for its socioeconomic status during the War of Independence between Spain and France. The war forced most of family to flee far from Cádiz in 1809 to Bath in England. Soon after the Spanish State seized the properties 
belonging to the, then, late MLC as a result of the strong connections three of his sons-in-law had with France. This period ends in 1816, coinciding with the distribution of the inheritance previously sequestrated by the Spanish authorities.

\section{The Spanish context of the early $19^{\text {th }}$ century}

At the beginning of the $19^{\text {th }}$ century, when the Ancien Régime still persisted, Spanish society was structured according to money and personal and kinship relationships. Under these circumstances, lineage or family interests prevailed over those of the individual, especially if this threatened the financial well-being of future generations with the subsequent loss of social status (Soria, 2007). In this patriarchal society, women were considered as physical, intellectual and morally inferior beings. Women were holders of their family's honour and, thus, their impoverishment could damage their family's reputation. This supposed weakness and vulnerability justified the deployment of a monitoring and protection system in which men's authority was unquestionable (Ortega, 1997). The contemporary law in force in Spain at the time, and more specifically in Castile where the Langtons lived, reflected the social structure of the time, thereby helping to reproduce it (Irigoyen, 2011). It reinforced the inferior status of women by preventing women from taking responsibility for their husband's debts.

The perception of women as inferior to men in the early $19^{\text {th }}$ century was re-enforced by the Roman Catholic Church whose Judeo-Christian beliefs emphasized a woman's moral defects (Capel, 1995). In a Catholic country such as Spain, the Church preached the submissiveness of wives, resulting in the confinement of women in the household, except for participating in charitable actions (De Giorgo, 1993). A century later this was still evident in Spain when the 1938 Working Rights Act, drawing on Catholic doctrine, enacted the "liberation of married women" from manufacturing workplaces so that they could raise their children and take care of their household (Fagoaga, 1963).

Male control of women in Spain in the early $19^{\text {th }}$ century was mainly enforced through the institution of marriage which was in practice a contract that allowed women to move between families: from their family and their subordination by their father to their subordination by their husband (Pérez et al, 1994). As head of the family a woman's father could determine who his daughter could marry to ensure that it was consistent with the family's social status. When married, the woman would then be under the control of her husband (López-Cordón, 1982; Irigoyen, 2011). Only widows could act as an independent person in their own right. This gave widows economic and moral power when they were named executor in their husband's will and guardian of their children (Lavrin and Couturier, 1979). Even then, however, women enjoyed fewer prerogatives than the pater familias, needing the protection of a close male relative (Ortega, 1997).

In Castile, where the Langton family lived for many years, matrimonial law had been regulated since the $14^{\text {th }}$ century by the Código de las Siete Partidas. This and the Regulations of Toro of 1505 (Leyes de Toro), in force during the period studied, regulated matters such as the dowries which the bride's family were expected to provide. This latter regulation also considered the amounts that the husband was expected to give as a matrimonial bond to ensure that the bride would be allowed to live at a standard previously provided by her family. In 1805 the Novísima Recopilación consolidated long standing laws relating to economic issues emerging at the time of marriage and affecting married women's patrimony. The Novísima Recopilación established, depending on their wealth, the maximum dowry that 
a father was expected to give to his daughter and that the groom could not provide as a matrimonial bond more than one tenth of his wealth or that the total expenses of the wedding could not surpass one eighth of the dowry received.

A married woman's economic rights were assured through the abovementioned regulations. Although appearing to protect these interests, the regulations were really meant to safeguard those of the family. Thus, when a woman married and her dowry and other private patrimony were given to her husband, he obtained the right to manage his wife's personal property. Any decision that a married woman made about her property would have required her husband's consent. In return for the power given to the husband over the marital properties he was expected to guarantee to meet his wife's needs. If the husband mismanaged a woman's property the Spanish regulations provided the opportunity for the wife to demand from her husband the return of the dowry to allow her to use this to provide for her household and family. With the family's well-being directly linked to the husband's status, if the husband died the family in general and the wife in particular might be placed in a difficult financial position, exposed to demands from creditors (Ortega, 1997). In this case, the woman or her heirs would get back the dowry and the private patrimony brought when she married in preference to any other creditor, for the Spanish regulations gave the wife a tacit mortgage on her husband's properties for the amount of the dowry. Everything that the marital couple had earned and purchased throughout the marital partnership was to be divided equally between the spouses and allocated to the surviving spouse and the late spouse's inheritors. If the woman died without children, her private patrimony had to be returned to her family. This emphasized the importance of the wife's line of ascent and descent, and in particular the strength of the family group from which the woman came (Chacón, 1995). Ultimately, the regulations confined the woman within the limits of a traditional and authoritarian family group (Couturier, 1985).

With the death of her husband, a widow received her dowry, half of the marital properties and a fifth of her husband's personal assets which remained after payment of the funeral expenses and pious bequests. In the specific case of the dowry, the wife or her heirs would only recover its value in money if this was estimated at the time of the marriage, otherwise they would be entitled to a payment which reflected current values at the time of the claim. Therefore, to record and value both spouses' private property was of great importance for the couple and also for their families. A Castilian custom, eventually incorporated in the Novísima Recopilación, presumed that the property of both husband and wife would be common property unless one of them could prove that they were the owner. According to the regulations, daughters had the right to the same share as sons in their parent's wealth. Thus, the Castile inheritance legal regime signified for the middle-classes a mechanism to prevent the neglect of widows and daughters and the expectation that men would take seriously their responsibilities for their family (Ortega, 1997; Fernández, 1997a). This protective regulation regarding widows, although apparently caring for their economic independence, was meant to ensure that they would not be impoverished, a situation which could also have affected the social standing of her family (Lavrin and Couturier, 1979). This also regulated the disposition of woman's goods after death, requiring that married women make a will (Goody, 1983).

The period studied was also characterized by a series of ideological and social changes promoted by the Enlightened thought which were echoed by mass media of the time. In the first half of the $18^{\text {th }}$ century the publication Defensa de las mujeres (Women' defense) by páter Feijoo had launched an intense debate about the underestimation of a woman's intellect. At the time it was not uncommon for women who were part of the gentry to know how to 
read, something which was very unusual for Spanish women in other social classes. To be able to write was even rarer among women (Ortega, 1997). According to Josefa Amar y Borbón (1790), the most renowned Spanish woman of the Enlightenment, with an education wives could manage better their household, promoting both their family's prosperity and that of society in general (Amar y Borbón, 1790). This well-informed wife is suggested as the ideal partner for a man involved in his business, in a similar way as Grey (1994) described the modern well-packaged wife. Josefa Amar y Borbón recommended that women should ask their daughters and servants for accounts, working out the total household expense of the year and balancing the expenses with the incomes. At the same time, these new ideas about women's intellectual capacities opened a subsequent debate regarding women's opportunities to choose a husband, thereby questioning the matrimonial institution as had been traditionally conceived (Ortega, 1997). The model of woman educated in a discrete, modest and frugal way began to emerge, in contrast to the aristocratic ideal of idleness and superficiality (Capel, 1995). Coinciding with these changes in the perception about women's capacities and marriage, in the years 1763-1764 the first Spanish female journal had been published, La Pensadora Gaditana (The Thinking Woman of Cádiz), in Cádiz and Madrid which demanded a woman's right to think and express her ideas, linking this possibility to "the freedom of a life without the terrible fastening of the marriage" (1786, p. 11). This was at a time when, from 1776, a series of royal regulations reinforced the protection of the father as unquestioned head of the family (Fernández, 1997b).

In maritime cities involved in overseas transactions, the participation of the wives of traders in family business management was very common during the long periods when their husbands were absent. In Cádiz, this implied that women belonging to the mercantile elite broke with their traditional role, until then associated with personal discretion and separation from the male world and the public sphere. Thus, in Cádiz concealment of women, which would involve the separation of areas at home into different places for women and men, gradually disappeared in the merchant class. This greater social openness is also evident in the new composition of dowries, very often directed towards objects dedicated to female ornament at that time (Fernández, 1997a). While representing their husbands in mercantile activities, these women associated with professionals and became familiar with legal issues such as the protection of their property rights. Fernández (1997a) mentions the cases of two women from Cádiz who, worried about the economic future of their families, confronted their husbands when they saw their property rights threatened. One feared that her husband's business would exhaust her dowry while the other discovered that her husband intended to deprive her of her rights as a widow through his will.

Spanish society at the time, conscious of the economic vulnerability of widows in general, tried to respond to their needs (Ortega, 1997). In the case of the widows of traders, the proceedings to liquidate the husband's business and to distribute the inheritance was long and expensive. The need to recover the assets which existed overseas, as well as the disrupting effect of wars, might prolong the process for years, thereby threatening a wife's status and sustenance. In Cádiz, concern about the necessities of women, together with the incursion of Cádiz women in the public sphere, prompted traders in the late $18^{\text {th }}$ century to develop patriarchal strategies which included increasing legacies that benefited daughters, granddaughters and nieces (Fernández, 1997a). Also, by means of ecclesiastical projects such as the Hospitalidad doméstica (Home Hospital Care), which were dedicated to caring for the destitute and sick in their homes, widows were expressly considered among those possibly 
needy of this care (Capelo, 2014) . Both measures sought to avoid honorable women having to leave the private sphere searching for resources should their husband die in poverty.

\section{The Langton-Dillón family}

The first antecedents of the Langton-Dillón family in Spain can be traced to Lorenzo Careu, a successful trader from Ireland who had set up his business in Cádiz in the early years of the $18^{\text {th }}$ century (Fannin, 2003). He had also sponsored the construction of a house in Ireland for poor widows who were admitted to live "in seclusion and spiritual application for the service of God" (Will of Lorenzo Careu, 1766). To protect the future of this charity, Lorenzo Careu bequeathed the usufruct of several estates in Cádiz. In addition, he left money to two hospitals for women, one located in Cádiz and the other in the nearby town of Sanlúcar.

In 1736, Lorenzo Careu's daughter married Nicolás Langton, also a native of Ireland. Her father provided a 20,000 pesos $^{1}$ dowry which Nicolás Langton invested in his father-in-law's company (Fannin, 2003). Subsequently, Nicolás Langton's eldest son, MLC, joined his grandfather and father's company as a manager (Lario, 2000, p. 155). In 1758 MLC married María Elena Wadding, who died in 1763. The couple had three daughters, all of whom died young. In 1766, MLC married María Dillón and produced, as Figure 1 shows, a large number of children, four of whom outlived their parents.

\footnotetext{
${ }^{1}$ In the period studied, the legal currency in Spain was the real de vellón. At that time there was a money of account, the peso, equivalent to 15 reales de vellón. The letters written by the Langton-Dillón family in 1810 , for example, refer to a rate of the pound in relation to the Spanish currencies, around 95 reales de vellón more or less, which was a little more than 6 pesos.
} 
Figure 1. Langton-Dillón Family tree

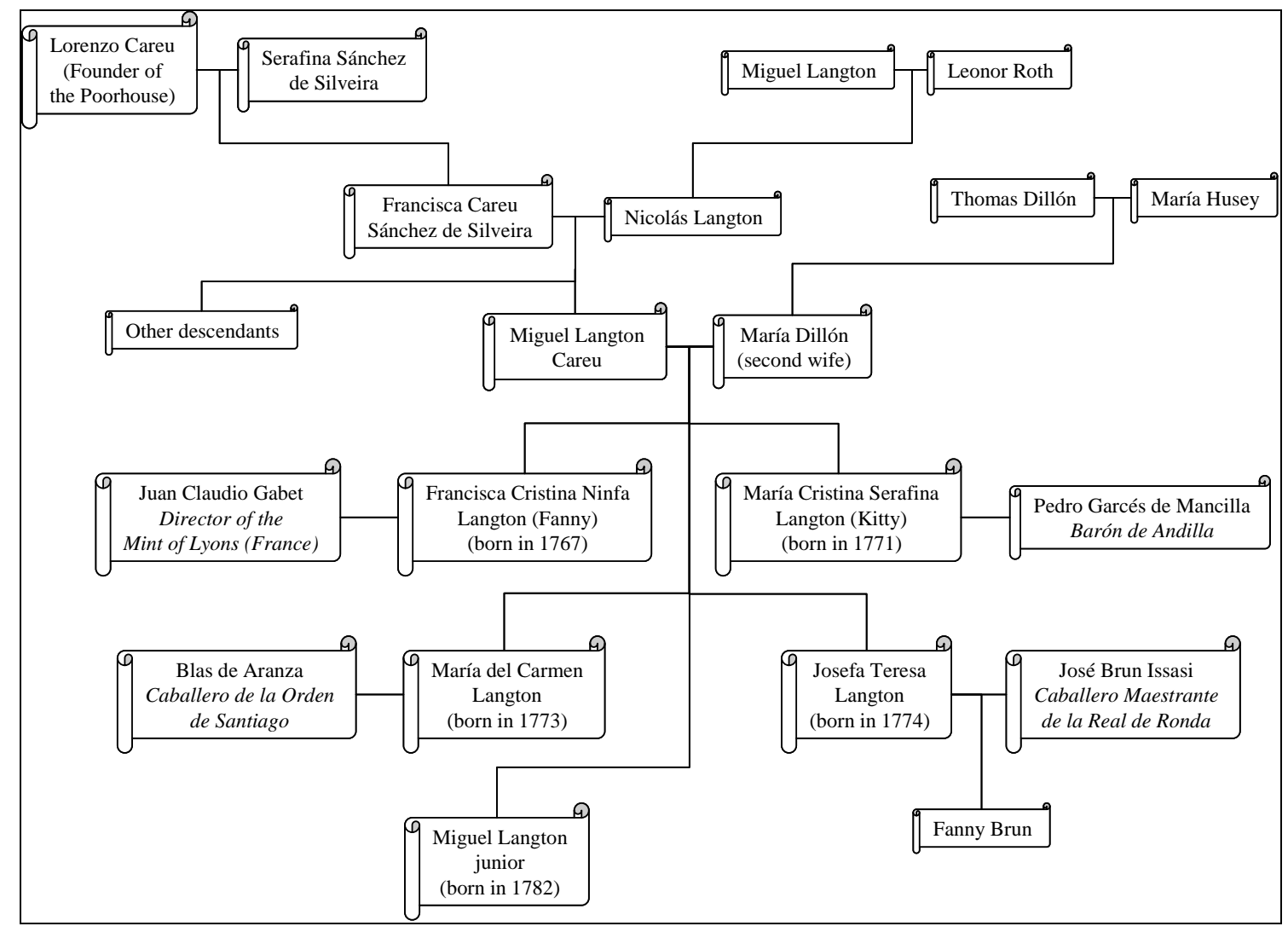

Source: Miguel Langton Careu's will (February $3^{\text {rd }}, 1810$, Disposiciones Testamentarias de Cádiz, Protocolo 1711, AHPC).

Until 1809, the highly profitable nature of MLC's business meant that the Langton-Dillón family enjoyed high living standards. However, in 1809 when it became certain that Cádiz would soon be under siege by the French most of the family was moved from Cádiz. Only MLC stayed in Cádiz with the object of closing down his business. María Dillón and MLC's granddaughter, Fanny Brun, escaped to Bath with Miguel Langton junior (ML junior hereafter) who spent long periods in London working as a volunteer for Spain. One of the daughters, Carmen Langton, accompanied by her six children, also provisionally took up her residence in Bath next to her family. Other Langton daughters, linked to France by their marriages, took shelter either in France or in Spain far away from the family nucleus established in Bath (see Figure 1). Meanwhile, ML junior acted as protector of all the women in the family now living in England.

When the family settled in Bath, ML junior was in his late twenties and was experienced in commercial business and accounting. ML junior and his father corresponded until the latter died in 1810 , these being the only letters sent by ML junior that are preserved in the archive ${ }^{2}$.

\footnotetext{
${ }^{2}$ The remaining letters are available because ML junior himself copied them in a letter-book.
} 
Apart from their content, these letters are also of some interest as an example of the dominating and dominant position of the Langton men. This can be clearly seen even in the most seemingly unimportant aspects of life, such as the way in which paper, a scarce commodity during these times of war, was used. An examination of letters by ML junior to his father indicates that there was an unequal sharing out of the writing paper between the different members of the family who were resident in Bath. In contrast to ML junior's writing, which occupied almost the complete piece of paper, the Langton women had to use the margins and spaces left by ML junior in his letters to MLC. Only María Dillón was permitted occasionally to occupy a preferential place on the piece of paper, writing at the beginning of the letter or in the middle of ML junior's writing.

Carmen Langton and Fanny Brun's complaints about their inability to have their own paper to write to Cádiz were persistent. This, as Thane (1992) notes, could be seen as an example where the agency of women was visible as they tried to lessen the domination over them. The insignificance of the women's discourse in the family correspondence compared to that of the men reflected and strengthened male domination, giving visibility to ML junior's perception about the capacities of women and that of the family and social hierarchy (Cooper, 1992; Ezzamel, 2002b). Most especially, denying the Langton women equal access to paper helped to effectively silence the Langton women, showing in this way "a disregard of their opinions, advice, expertise, and feelings" (Lehman, 1992, p. 265), making them less visible even in their narrow family environment and incarcerating them even more within gender tasks inside their domestic space (Kim, 2004). The writings of these women also show how the younger women were unhappy with this domination and social opacity.

\section{Accounting for women's property rights: enforcing male domination}

The female property rights emerging throughout MLC's first marriage became known through MLC's will given in 1798, when he specified his first wife's dowry as well as the value of her other personal patrimony. All these data, mainly obtained from accounting, allowed that he could calculated at that time the total amount that his first wife's only inheritor -his grandson Patricio Cruisse y Langton- should come into possession of. This amount should be delivered to Patricio when he got marriage or reached the full age, MLC having signed a promissory note before the notary for this concept the year before. This evidence shows the utilization of accounting to ensure that late woman's capital -initially preserved to protect her and calculated in detail- would returned to her own family group, flowing upwards or downwards.

The economic consequences of MLC's second marriage were found in his accounting records as well as in his last will given in 1810. At this time María Dillón became owner of her dowry and some MLC's gifts in jewels, her only capital at that time (see this entry in Figure 2), this amounting to 133,497 reales de vellón. However, there is no reference to a dowry statement. At the time of his marriage MLC also made note of his personal capital, $1,811,376$ reales de vellón, resulting from different inheritances, half of the marital property in the first marriage and profits obtained during his widowhood. Later, he recorded in his accounting books any increase in his personal capital from the inheritances received from his parents and offspring from his first marriage ${ }^{3}$. As a result of these inheritances his wealth

\footnotetext{
${ }^{3}$ In 1801 when Patricio Cruisse y Langton died without issue, MLC was his only heir.
} 
increased by 699,068 reales de vellón, which meant that at the time of MLC's death his personal capital amounted to 2,510,444 reales de vellón. The identification of the capitals provided by MLC and María Dillón reflected at the beginning of the marriage the marital economic regime, would allow the later differentiation between the spouses' own personal patrimony and shared possessions. The generalized assumption about women's inability to honestly obtain resources outside the home, as "women have got in their families their typical (particular) employment" (Amar y Borbón, 1790, p. XII) and the subsequent need to impede any damage to the family's status in case of widowhood, made it necessary to have accounting records to safeguard the rights of married women, assuring them of the means needed to live well according to their social class and avoiding the need to go outside the family. Accordingly, in a juridical context that could favour married women through the preservation of their property rights, the family's accounting was a means to maintain male dominance.

Throughout the marriage, according to the Castilian laws the property of women was completely under the husband's control, thereby enforcing the wive's subjugation. This is clear in MLC's mercantile accounting books where, as with other property under the male's control, the dowry and the personal property of his wife were entered and clearly identified. From the perspective of the wife's relatives, the possibility that the wife's capital would be returned to her lineage should she die before her husband or that the wife needed her family's help in case she was widowed, meant that they had an strong and clear interest in everything concerning the wife's capital, including accounting for it in an accurate manner.

As each of the Langton-Dillón daughters were married, MLC maintained specific accounts with each of his daughters, recording the amounts paid on their behalf or received by them. These accounting sources regarding dowries and other gifts to the daughters would be later taken into account for the distribution of MLC's inheritance. However, in the particular case of his daughter Fanny MLC's protection went even further, writing off the amounts previously advanced to her, apart from the dowry. In this case, accounting was a useful instrument to classify these amounts as alms instead of advances to the daughter, so as to not diminish the amount inherited from her father. The utilization of accounting records in the Langton-Dillón family as a way to prove women's patrimony value and to facilitate recovery of property helped to ensure the financial well-being of the women who were confined in the household, thereby preserving the family's social standing. MLC's undiminished concern and responsibility for the well-being of the Langton-Dillón women was clearly present in provisions in his last will, where he named ML junior and his relative, Agustín Butler, as executors. It shows how the egalitarian laws applicable in Castile were recognised. Consistent with Castilian laws, a fifth of MLC's estate was to be reserved for the payment of the burial, funeral and pious bequests. The will also stipulated through a private document a series of donations to several charities which in total amounted to 2,700 pesos (see Figure 2). Some of the institutions which profited from this legacy were intended specifically to relieve women's hardships.

Through his will, MLC also became one of the most important sponsors of the Hospitalidad doméstica in the year 1810 (Fernández, 1997a). A similar protective attitude toward women was exerted by MLC and his son when they acted as patrons of the poor widows' hospital founded by Lorenzo Careu in Ireland. This shows their concern for helping 'defenseless' women in general and the adoption of patriarchal strategies typical of other contemporary traders aiming to avoid women being left destitute (Fernández, 1997a). The remaining part from the fifth reserved for the payment of burial, funeral and pious bequests 
was to be distributed in the following way: for the widow "30,000 pesos as a proof of the affection that I have always felt towards her and with which she has repaid me", to be invested in the way he had previously indicated. According to the latter document, from this 30,000

the sum of 6,000 pesos as follows was to be deducted

Pesos 750 For 1.500 Masses

2,400 Public charities

1,113 Private charities

1,737 Legacies

Pesos 6,000 Which you will take note of.

(Letter from Agustín Butler to ML junior, written on April 16th 1811 in Cádiz, 0770/1/2/11, BRO)

What remained from this fifth part after the subtraction of the 30,000 pesos would be divided in five equal parts among the four surviving children and only grandchild, Fanny Brun (Will of MLC, 1810).

Figure 2. The share of Miguel Langton Careu's will

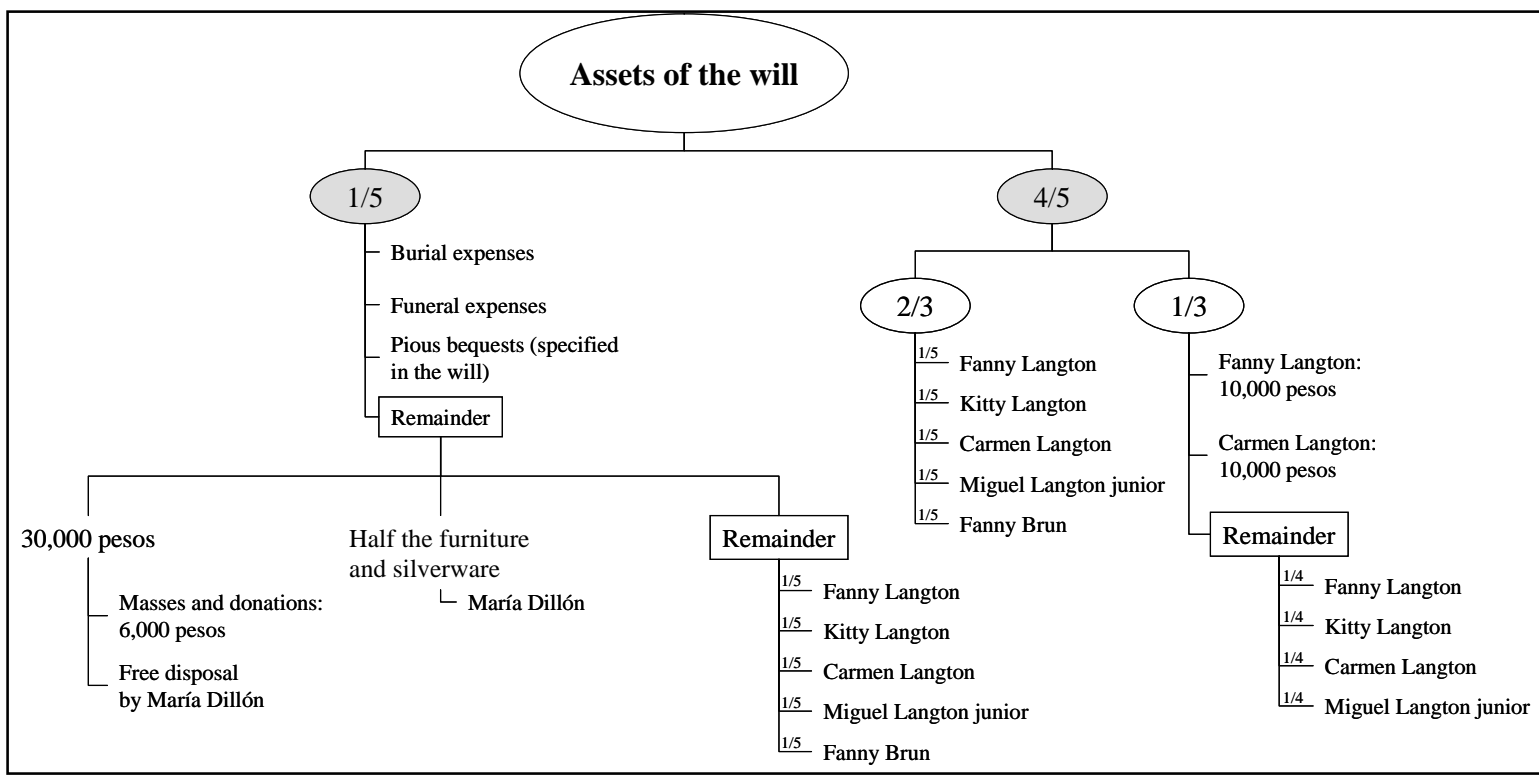

Source: Miguel Langton Careu’s will (Ibídem).

After having applied one fifth of his estate, of the remaining four fifths two thirds were to be distributed equally among his children and the other one third for bequests of 10,000 pesos to his daughter Fanny and 10,000 to his daughter Carmen (see Figure 2). MLC used the will to justify favouring his daughters Carmen and Fanny to alleviate their misfortunes. This 
clause was related to the links of his sons-in-law with the French and the subsequent problems for their wives with Spanish authorities ${ }^{4}$ caused by the French invasion of Spain. Furthermore, he explained that he had in no way disadvantaged his granddaughter who would receive an inheritance from her father. In a codicil, MLC expressed his wish that his half of the furniture and silverware of the house, acquired during the marriage, should be inherited by his widow (July $15^{\text {th }}, 1810$ ).

\section{Langton-Dillón women's perception of accounting}

María Dillón's will shows a woman's concern and self-perception about the importance of accounting for a married woman's future welfare in Castile. She repeatedly states in her will that she trusted that her husband's personal capital at the time of their marriage could be ascertained from MLC's accounting books, thereby allowing the calculation of the couple's common properties and the subsequent allocation of half this property to herself or her heirs: "because of the full satisfaction that I have with respect to my husband's way to behave and his scrupulous conscience in money matters and for the same reason I am referring to the books themselves regarding his capital" (Will of María Dillón, year 1791). As a reputable traders' wife she trusted accounting as a technology to guarantee her own welfare and that of her lineage.

When each of the Langton-Dillóns's daughters was married MLC credited each daughter's account with the respective dowries given in money and clothes, altogether 1,074,056 reales de vellón. Despite testamentary reports that dowry statements were not always given, one of the daughters (Fanny Brun's mother), married to a civil servant, referred in her own will to a private document written in her handwriting where she had specified her dowry, groom's gifts and some legacies. This is one example of how women themselves claimed their rights. This private document incorporated accounting information such as inventories and valuations produced by herself. Although Langton women were not used to keeping longterm records, such as Komori (2012) has shown were kept by the Japanese, they showed a great interest in the existence of records regarding their patrimony as a way to protect themselves for the future. This use of calculative technologies to provide women with some assurance about the future recovery of economic resources coming from their parents and husbands, as with María Dillón and Josefa Teresa, would allow them to remain in the households instead of seeking the necessary resources outside.

\section{Accounting as a gender-based technology in the household}

Throughout his marriage MLC recorded the money given to his wife in an account called household expenses (gastos de casa) which was kept as part of his mercantile accounting. The existence of this record reinforced the need for his wife to render accounts, thereby increasing her subjugation. This was also confirmed after the family moved to Bath when ML junior informed his father that all of the amounts withdrawn from the bank for his mother would be recorded in the same way.

\footnotetext{
${ }^{4}$ A letter addressed by ML junior to General Blake asking for his mediation with Spanish Authorities shows how Carmen and Fanny were the first to be affected by the Spanish reprisals (February 20 $0^{\text {th }}, 1811$ ). Later Kitty also was affected because of her husband's association with the French.
} 
During the Langton family's time in Bath, the evidence shows that María Dillón made significant contributions in controlling her own expenses. As a result of ML junior spending long periods in London it was very difficult for him to have effective control over household expenditures. At the very most, ML junior could have dealt with the calculation of total expenses each time that he visited the family in Bath, at which time early in their move to England he would write to his father informing him of his mother's household spending. ML junior also sent to his father information collected about the expenses of the other LangtonDillóns resident in the same home address, including his niece Fanny Brun whose expenses were controlled by her grandmother, his sister Carmen and ML junior himself. Calculations concerning Carmen recorded the amounts spent from cash that ML junior had withdrawn from the bank. References that ML junior made to MLC about the type of Carmen's expenses, such as "merely for shoes, washing etc" (April 14 ${ }^{\text {th }}, 1809$ ), suggest a female interest in preserving household vouchers or other records.

The letters by ML junior show that the Langton-Dillón women had little or no involvement in economic discussions but do confirm their special interest in the domestic economy. This was also evident in their collaboration in the rendering of accounts to MLC, which kept track of the women's ordinary expenses and controlled items such as money spent on clothing. However, the evidence suggests that the women did not carry out a detailed record-keeping in contrast to the findings of other studies in different contexts (Kirkham and Loft, 2001; Walker, 2006; Komori, 2012). The Langton-Dillón women, while involved in tracking their own household expenses, even giving accounts from woman to woman as Amar y Borbón (1790) suggested, only fulfilled a stewardship function with the resources received, finally rendering accounts to the head of the family with respect to the expenses incurred. This made clear the (in)competence in managing the resources received that Spanish society expected of women as the "Angel of the Home" and at the same time reinforced the private patriarchy in a similar manner to Victorian Britain (Walker, 1998).

As previously noted, ML junior's letters to his father included some Langton-Dillón women's writings about domestic matters, notably the household economy. In one case, having just arrived in England, Carmen complained how expensive and luxurious everything was in Bath: "we see it but do not need it, I buy which is very essential and nothing more" (April 14th, 1809). In a similar manner, her mother later wrote asking her husband to bring with him the good linen "as it is very expensive here" (March 14th, 1810). This clearly shows that the Langton-Dillón women, adopting a more modest way of life that was required by their economic circumstances (Capel, 1995), took some of the responsibility for cutting back their expenses.

In contrast to María Dillón's expenses, expenses related to other family members were entered by MLC in specific current accounts for each member of the family. Fanny LangtonDillón, however, was an exception for her father stated in his will that the amounts advanced to her were to be written off. Thus, MLC was putting on the same level his wife, whom he was required to provide for according to the law, and his daughter Fanny. Here, the use of the language of accounting with its aura of precision and objectivity was perpetuating (Cooper, 1992) and helping to legitimize the existing social order (Ezzamel, 2000b), in particular the male role as the women's protector. The existence in the family's accounts of specific accounts for each of the married daughters helped to preserve their daughters' property rights, thereby facilitating the inheritance process from their parents and impeding any damage to their own lineage because of any potentially future defencelessness. 
ML junior's interest in household accounting went beyond his father's concern for accounting for money provided to his wife and other members of the family. Thus, once the family was settled in Bath, he started to develop his own estimates of the average monthly expenses of the two adult women resident in the house, his mother and his sister. This information was also reported to his father. In spite of the enlightened recommendations about woman's more active role in household governance and accounting (Amar y Borbón, 1790), these calculations about expenses originated in the male sphere although with the collaboration of women in lower level tasks and, thus, evidence a gender division of competencies (Ciancanelli, 1990; Kirkham and Loft, 1993). Other studies have found similar calculations of average individual or family expenses, carried out in some cases by women (for example, Komori and Humphrey, 2000; Komori, 2012) and in others by men (Carnegie and Walker, 2007b). ML junior also provided to his father reports about the average expenses, explaining the different purpose of the expenses and measures taken to promote thrift in accordance with his accounting calculations. The calculations of above average spending in effect resembled individual budgets of expenses, facilitating short-term decisionmaking with respect to acceptable expenses for food, servants, accommodation and clothes. Thus, this shows the utilization of accounting for controlling the cost of living (Komori and Humphrey, 2000; Ezzamel, 2002a; Komori, 2012).

The use of budgets for general household expenses, with budgeting the most commonly advocated technique to manage the home according to Walker and Llewelyn (2000), had specific implications for the women living together in the Langton-Dillón's home. Firstly, monthly calculations worked as a measure of the women's responsibility in the consumption of family resources. Secondly, once these expenses were estimated, instead of creating a greater equality inside the family (Komori and Humphrey, 2000) they could work to reinforce domestic power relations through a fixed allowance. Vogler and Pahl (1994) assert that this way of managing economic resources in the household is the worst option for women, contributing to worsening inequalities in decision making by spouses. Thirdly, there was particular emphasis on the type of expenses incurred by women, not for clothes but for shoes, which is consistent with the male opinion about the financial irresponsibility of women (Llewellyn and Walker, 2000). It also illustrates the male concern about the presence of "extravagant" female expenses and his responsibility to monitor the extravagance. This environment of monitoring caused anxiety in the Langton women about the domestic expenses as is evident in the short notes that they addressed to MLC. It acted as an instrument for restricting women's freedom in their management of the expenses (Walker, 1998; Komori, 2007), contributing through the family budget to perpetuating the subordination of women and to enshrine, therefore, the existing gender inequalities. This male leadership in accounting carried out in the Langton-Dillón's household could be fostered, according to Kim (2004), by the contemporary social stereotype of women in spite of the incipient discourse about a desirable role for women in the household economy (Amar y Borbón, 1790).

MLC's death on July 1810 and the subsequent appointment of ML junior as executor together with Agustín Butler, who worked from Cádiz, reinforced the son's role in protecting the Langton-Dillón women. These appointments required that both executors wrote to one another from the beginning about economic and accounting matters. With MLC's death the movement of funds from Cádiz became very difficult; this situation further worsening from 
December 1810 when all the inheritance within reach in Spain together with the accounting books were confiscated by the Real Junta de Represalias ${ }^{5}$. Nevertheless, in February 1811, ML junior gained access to the money his father had deposited in two banks in Bath. Part of the assets was then placed in public bonds which would guarantee a fixed interest for the inheritors. ML junior ensured that a clear presence was provided in his accounts for each of these transactions.

With the new economic circumstances of the family, ML junior began to make annual calculations concerning average family incomes and revenues, looking for the balance between the incomes and expenses of the family, as should have been expected from Spanish women according to Amar y Borbón (1790). Through these calculations ML junior was able to prepare an annual budget for the family settled in Bath. Based on this budget, ML junior wrote to his sister Kitty Langton as spokesperson of María Dillón, explaining to her the type of domestic expenses that they could afford with the available income. ML junior, on behalf of his mother apologized for not being able to pay for more expenses. The use of information from accounting records allowed ML junior to adopt an apparently objective and impersonal manner (Hines, 1992). Ultimately these budgets were useful in deterring Kitty from going to live in Bath.

\begin{abstract}
Maman entrusts me with telling you on her behalf ... that her limited situation does not afford her to be more liberal with her children, as is her kind-hearted wish, but she will hardly have enough for financing the most essential ... since the excessive high cost of living in this country makes it that even this costs more that the two would cost in Spain, and the money in the public funds only produces four and five per cent of interest (August $20^{\text {th }}, 1811$ ).
\end{abstract}

In a society dominated by males, accounting provided a masculine depiction of life working at the service of economic goals (Dillard and Reynolds, 2008), if necessary pushing the women's maternal instinct into the background (Hines, 1992). Unlike the household accounting carried out by women evidenced by Komori (2012), which was at the same time a means of expressing motherhood and teaching money-management to the children, in the Langton-Dillón home it was the man who used accounting figures in this rational and disciplining way. The repeated references to the relationship between incomes and expenses reflect a male concern about the possible insolvency of the family and the subsequent loss of status. This worry, evident in the formulation of an annual budget, required and justified that the mother carried on rendering accounts (Komori and Humprey, 2000; Carnegie and Walker, 2007b).

Dissuaded through male budgets from incurring more expenses, María Dillón could help to balance incomes and expenses in the household only in a limited manner. As a widow, María Dillón had become the only administrator of all her patrimony, at the same time being responsible for the payment of all her expenses, as stated the Castilian regulations. This greater independence and her subsequent new economic status could imply a greater freedom (Lavrin and Couturier, 1979) that should have meant less need to render accounts. However,

\footnotetext{
5 This institution was created in Spain with the object of confiscating all kinds of goods, correspondence and accounting books belonging to the French, according to the Regulation (Instrucción) enacted on March $28^{\text {th }}$, 1809.
} 
the evidence available indicates that the widow carried on rendering accounts about the resources that she managed herself, contributing to prolonging her submission.

ML junior as legal administrator of his niece's inheritance also monitored her expenses and incomes after MLC's death, estimating average income. The necessary balance between incomes and expenses was utilized as an argument to decide whether to spend or to invest in the musical education of Fanny Brun. ML junior even established a hierarchy for Fanny's expenses in accordance with her financial resources, that did not affect Fanny Brun's necessary spending on clothes. For "the domestic middle class woman of the $19^{\text {th }}$ century [...] dress offered a means of projecting and expressing the bodily self in the public sphere" (Walker and Carnegie, 2007, p. 241). This was especially necessary for a woman who was of marriageable age. This evidence shows how accounting emphasized the importance of expenses which promoted women's role as an ornament in the patriarchal society, contravening the enlightened ideas about desirable woman's modesty (Capel, 1995). This hierarchy for expenses is evident when ML junior expressed to Agustín Butler that a father needed to attend to the expenses generated by his daughter's primary necessities, unpaid for a long time, before other more extravagant ones, such as the projected portrait of his daughter: "let him pay for her clothing first to you and then talk of pictures" (February $5^{\text {th }}, 1812$ ). The utilization of this hierarchy for household expenses can be seen as a way to build the personality and character (Komori, 2012) but also as a means to refrain men's expenditures (Komori, 2007).

ML junior's general knowledge about the household's income and expenses helped him to make decisions to increase his and his mother's income and to improve their standard of living, as happened when they purchased a house and some land. These findings are similar to those of Komori and Humphrey (2000) and Komori (2012) regarding the link between household accounting and the search for a better lifestyle, although women's involvement in this use of accounting was less active in the Langton-Dillón family's case. The absence of the involvement of women in major spending decisions contrasts with the evidence provided by Komori (2012) in the context of Japan, although it has also been found by Carnegie and Walker (2007b) among Australian households.

Prejudices about women's capacites are not universal, as Komori (2008) has shown. According to ML junior women did not know about accounting or business. Referring to the female members of a banking family, the Byrnes, linked to his grandmother's inheritance in Ireland, he wrote that he "did not expect to obtain any satisfactory information from them as women are seldom well-informed on money matters especially when not personally interested" (August $6^{\text {th }}, 1812$ ). This asymmetry in male perceptions about women and men's interest regarding non-domestic economic matters is consistent with the findings of several studies about the scarce representation of women in non-domestic accounting in the $18^{\text {th }}$ and $19^{\text {th }}$ centuries (Wiskin, 2006; Virtanen, 2009; Walker, 2003, 2006). ML junior felt obliged to know everything regarding the family's finances. This is evident when after he commenced action to recover his maternal grandfather's property inheritance he felt forced to apologise for not having enough information about this part of the family's business at the time of the invasion of Spain by the French. ML junior, as a man and now patriarch of the family, felt guilty for being ignorant of these issues. 


\section{Accounting for defenceless women}

From his arrival in Bath, ML junior kept the same accounting system as his father, charging the different family members for the cash used. After MLC died, his son continued to maintain the accounts of the different family members for the amounts of money that they had requested be withdrawn from the bank. This information was used by ML junior to manage the welfare of the women. In the case of Fanny Brun, the difficulties in recovering from her father money to cover her expenses, advanced to her by her grandmother, meant that ML junior resorted to accounting in order to safeguard María Dillón's welfare. To try and get José Brun (Fanny's father) to pay for his daughter's expenses, ML junior made reference both to María Dillón and her granddaughter's incomes and expenses, known by ML junior, and to Fanny's outstanding bills. After receiving a letter from José Brun, claiming that he would not pay for any of his daughter's bills until he knew the effective part corresponding to her in MLC's inheritance, ML junior wrote to him again, comparing Fanny's income with her own normal annual expenses:

In order to refute that pretence ... I have now sent him a copy of the (provisional) Repartimiento (sharing) ... by which he will see that poor Fanny has no claim to more than four hundred and odd pounds upon the money in England ... the interest of which in the 5\% Navy stock after deducting the income tax is not more than $£ 20$ a year whereas her expenses merely for dress, masters, \& doctors, for no charge is made for maintenance, amounts to about $£ 70$ a year, the balance of which my Mother disburses every year and he owes it to her and should pay it (letter to Agustín Butler explaining his last letter to José Brun, December 2nd, 1813).

Accounting appeared again to be giving a male depiction of the family affairs (Dillard and Reynolds, 2008), this time on the occasion of an orphan's defencelessness, thereby enforcing a man's legal duty to meet the needs of his offspring, making visible accounting records about women specifically with the aim of promoting the welfare of the widow upon which depended the family honour.

Carmen and Kitty Langton's specific experiences are also worthy of mention because of the extreme situations in which they lived and ML junior's utilization of accounting in this respect. In the case of the former, when she became a widow in 1813 the details of MLC's accounting, remembered by ML junior, allowed her to know the exact amount to be claimed from her husband's testamentary, as Carmen's dowry was completely invested in his remaining capital with the exception of the balance of a bank account opened in England. The explanations sent to the family's attorney in Cádiz specified the amounts that Carmen and her husband had received and paid since their marriage. The circumstances of Kitty Langton were different. She had been one of the beneficiaries of advances from the inheritance. The amounts that she received, together with the interest accrued, were controlled in an account similar to the one for María Dillón. Her husband's connections with the former Napoleonic Regime provoked the sequestration of his patrimony by the new French authorities, making the recovery of Kitty's dowry very difficult. This prompted ML junior to use his knowledge about the capital to be inherited and the capital previously advanced to Kitty in order to 
reinforce the husband's sense of full responsibility with respect to Kitty's well-being, making clear the little cash that she would receive. ${ }^{6}$

The financial plight of Carmen and Kitty Langton, and Fanny Brun, show how the Langtons' accounting records reinforced a male discourse when ML junior acted as his relatives' protector (Dillard and Reynolds, 2008), revealing the usefulness of household accounting records in safeguarding women's property rights and, as a result, their welfare in extreme cases. This role of accounting as a shield of women's rights with respect to their husband's patrimony or other male relatives could be more effective in the case of married women taking action against their husbands or their inheritances as a result of specific laws which applied in Spain at that time, but less useful regarding the recovery of the granddaughter's outstanding expenses. This accounting role was also important for the women's family, as they were the subsidiary responsible people whether the husbands, Carmen's and Kitty's, or Fanny's father failed in their responsibilities.

\section{Conclusions}

This study has focused on the household accounting of a Catholic family of Irish ancestry, embedded in a very patriarchal context, who were representative of the Spanish uppermiddle-class in the early $19^{\text {th }}$ century who lived for many years in the major trading city of Cádiz. At that time a Spanish woman's dowry and other properties passed to her husband at the time of their marriage but could be recovered after the dissolution of a marriage, in contrast to Anglo-Saxon laws which withdrew a woman's property rights forever after she married. This difference in the treatment of married women has provided the opportunity to show the mutable character of patriarchal ideology and the accounting practices related to them (Walker, 2003).

Accounting was a practice that contributed to the subjugation of women by men who used accounting to control the property of women, their incomes and expenses throughout marriage. This was a control that was also used by the women's own family. Accounting provided the means to preserve a woman's property rights and provide them with economic resources in the future, thereby denying the need for women to seek economic resources outside the home. Women were conceived as merely the means for the circulation of property between two families (Irigoyen, 2011); accounting providing the proof of women's patrimony value and the means to facilitate their recovery in this cosification process.

Although accounting provided men with a powerful means to subjugate women, the material presented has shown how the Langton-Dillón women demonstrated confidence in accounting and related calculations, which were usually the exclusive province of men, to guarantee their own economic welfare and that of their descendents. They were allowed little

\footnotetext{
${ }^{6}$ The following letter to Kitty's husband confirms that little would be received in the form of cash:
}

I can tell you that my father's capital in credits in Europe including the dowries paid in advance to four of my sisters amounted on the date of his death to 3,434,202 reales de vellón more or less, of which subtracting half of the shared possessions that belongs to my mother and the large legacies of the fifth that amount to about 500,000 reales, besides the legacies of 300,000 for my sister Francisca and Carmen, reduce a lot the capital that will go to [Kitty] and me, so that I believe that [Kitty] could receive about 400,000 reales de vellón more or less (November $10^{\text {th }} 1814,0770 / 1 / 3 / 195, \mathrm{BRO}$ ). 
or no involvement in economic discussions but still they developed a strong interest in the domestic economy, fulfilling a stewardship function for the resources received. This stewardship function (Walker, 1998) was only partially relaxed with the economic independence of a wife after she was widowed.

Gendered accounting jurisdictions existed in the Langton-Dillón's household (Carnegie and Walker, 2007b). While women were involved in keeping track of their ordinary expenses, trying to reduce them and exceptionally controlling their personal patrimony, the usual practice was that the head of the family collected and analyzed the information provided by women. This information could be used to create budgets both to ensure that there would not be any financial problems which would threaten the social status of the family and to improve their standard of living. At the same time this was restricting women's freedom inside the household and maintaining the existing inequalities. The little involvement of the Langton women in the household's accounting and management, contrary to the evidence provided by Komori and Humphrey (2000) and Komori (2012), confirmed accounting as a language for reproducing and enforcing male values inside the family (Hines, 1992).

The study has shown how accounting practices were justified to promote the welfare of the Langton women and the responsibility of men as their protectors when they confronted difficult financial situations, such as widowhood or the financial ruin of their husbands. This further confirmed the stereotype of women as ignorant, and incapable, of developing a knowledge of financial matters, showing how this is "sharpened in the home" (Llewellyn and Walker, 2000, p. 470), thereby justifying men disregarding the opinion of women (Lehman, 1992). It has also been established that men regarded women as irresponsibly extravagant, thereby further vindicating the need for men to exercise detailed control of the family's finances for which a detailed accounting of the spending of the women was an essential requirement. The use of accounting practices reinforced the dominating male position in the family promoting the view that the role of women was as an ornament and in need of a good husband, thereby enshrining marriage, the major institution for the subjugation of women at the time.

In conclusion, accounting carried out by men helped to legitimize the social order where dominating men were seen as the protector of women, denying at the same time women the ability to understand business and/or accounting. Nevertheless, in addition to Komori's (2012) work which has shown that women have sought to take responsibility for the family's economy, the present study suggests that men behaved in a similar way, seeking to control male and female extravagance through accounting practices. At the same time, this male accounting left some room for women's agency when trying to demonstrate their frugality through their private records, according to the contemporary enlightened discourse about woman's desirable higher responsibilities in household management.

The Langton-Dillón family's accounting, used for recording women's property rights and perceived by women as a reliable source of information, was conducted by men who restricted the roles of women through accounting. By using accounting practices to shield supposedly defenseless women in extreme situations, this reinforced male domination which at the time was exerted by a husband over his wife, between brothers and sisters and fathers and daughters, a reflection of the influence of a specific socio-cultural and regulative context (Irigoyen, 2011; Chacón, 1995). 


\section{PRIMARY SOURCES}

AHPC, Archivo Histórico Provincial de Cádiz, Protocolos notariales de Cádiz, Bundles 1632 and 1711.

BRO, Bath Record Office, Langton family Papers, References 0770/1 and 0770/2.

WRO, Worcester Record Office, Fanny Brun papers, Reference BA 81, 705.24/784

\section{SECONDARY SOURCES}

Amar y Borbón, Josefa (1790), Discurso sobre la educación física y moral de las mujeres, Madrid: Imprenta de Benito Cano.

Arbiol, A. (1704), La familia regulada, cited by Irigoyen (2011).

Calás, M.B. and Smircich, L. (2006), "From the 'Woman's point of view' ten years later: Towards a feminist organization studies", in Clegg, S.R., Hardy, C., Lawrence, T.B. and Nord, W.R.(eds): The Sage Handbook of Organization Studies, Sage, London, pp. 284347

Cantero, M.A. (2007), “De 'Perfecta casada' a 'Ángel del hogar' o la construcción del arquetipo femenino en el XIX”, Revista Electrónica de Estudios Filológicos, 14.

Capel, R.M. (1995), "Mujer, sociedad y literatura en el Setecientos español”, Cuadernos de Historia económica, No. 16, pp. 103-119.

Capelo, M.D. (2014), "La contabilidad de una organización benéfica en tiempos de la ilustración. El hospicio 'Casa de Misericordia' de Cádiz (1784-1790)”, DE COMPUTIS Spanish Journal of Accounting History, 20, pp. 7-36.

Capelo, M.D., Araújo, P. and Álvarez-Dardet, M.C. (2005), “Accounting regulation, inertia and organisational self-perception: Double-Entry adoption in a Spanish Casa de Comercio (1829-1852)", Accounting, Business and Financial History, Vol. 15 No. 2, pp. 145-169.

Carnegie, G.D. and Walker, S.P. (2007a), "Household accounting in Australia. Prescription and practice from the 1820s to the 1960s", Accounting, Auditing \& Accountability Journal, Vol. 20 No. 1, pp. 41-73.

Carnegie, G.D. and Walker, S.P. (2007b), "Household accounting in Australia: a microhistorical study", Accounting, Auditing \& Accountability Journal, Vol. 20 No. 2, pp. 210-36.

Carmona, S. and Ezzamel, M. (2016), "Accounting and lived experience in the gendered workplace”, Accounting, Organizations and Society, Vol. 49, pp. 1-8.

Carrera, N., Gutiérrez, I. and Carmona, S. (2001), "Gender, the state and the audit profession: evidence from Spain", The European Accounting Review, Vol. 10, pp. 803-15.

Castaño, J.A. (1986), "Los contratos matrimoniales; reflejo de la sociedad alicantina del Antiguo Régimen”, Revista de Historia Moderna, Vol. 5, pp. 175-93. 
Chacón, F. (1995), "Hacia una nueva definición de la estructura social en la España del Antiguo Régimen a través de la familia y las relaciones de parentesco", Historia Social, Vol. 21, pp. 75-104.

Ciancanelli, P., Gallhofer, S., Humphrey, C. and Kirkham, L. (1990), "Gender and accountancy: some evidence from UK", Critical Perspectives on Accounting, Vol. 1, pp. $117-44$.

Connor, R.E. (2004), Women, accounting and narrative. Keeping books in eighteenth-century England, Routledge, London.

Cooper, C. (2008), "The non and nom of accounting for (m)other nature", Accounting, Auditing \& Accountability Journal, Vol. 5 No. 3, pp. 16-39.

Cooper, C. (2001), "From women's liberation to feminism: reflections in accounting academia", Accounting Forum, Vol. 25 No 3, pp. 214-45.

Couturier, E. (1985), "Women and the family in Eighteenth-century Mexico: law and practice", Journal of Family History, Vol. 10 No. 3, pp. 294-304.

Dambrin, C. and Lambert, C. (2008), "Mothering or auditing? The case of two Big Four in France”, Accounting, Auditing \& Accountability Journal, Vol. 21 No. 4, pp. 474-506.

De Giorgo, M. (1993), "El modelo católico", in Duby, G. and Perrot, M. (Eds), Historia de las mujeres en Occidente. Tomo 4. Santillana, S.A., Madrid, pp. 183-218.

De León, Fray Luis, (1583), La perfecta casada. Biblioteca Virtual Manuel de Cervantes. http://www.cervantesvirtual.com/nd/ark:/59851/bmc0p0w9.

Dillard, J. and Reynolds, M.A. (2008), "Green Owl and the Corn Maiden", Accounting, Auditing \& Accountability Journal, Vol. 21 No. 4, pp. 556-79.

Duff, A. (2011), "Big four accounting firms' annual reviews: A photo analysis of gender and race portrayals", Critical Perspectives on Accounting, Vol. 22, pp. 20-38.

Ezzamel, M. (2002a), "Accounting for private estates and the household in the twentiethcentury BC Middle Kingdom, Ancient Egypt", Abacus, Vol. 38 No. 2, pp. 235-62.

Ezzamel, M. (2002b), "Accounting and redistribution: the palace and mortuary cult in the middle kingdom, Ancient Egipt”, Accounting Historians Journal, Vol. 29 No.1, pp. 61103.

Fannin, S. (2003), "Carew, Langton and Power, an Irish trading house in Cádiz, 1745 1761 ”, I Coloquio Internacional "Los Extranjeros en la España Moderna”, Málaga, Tomo I, pp. 361-72.

Fagoaga, M. (1963), "El fuero del trabajo y la doctrina social de la iglesia", Revista de Política Social, 58 (April-June): 23-45.

Fearfull, A. and Kamenou, N. (2006), "How do you account for it? A critical exploration of career opportunities for and experiences of ethnic minority women", Critical Perspectives on Accounting, Vol. 17, pp. 883-901.

Fernández, P. (1997a), El rostro familiar de la metrópoli. Redes de parentesco y lazos mercantiles, 1700-1812, Madrid: Siglo Veintiuno de España Editores, S.A. 
Fernández, P. (1997b), "El declinar del patriarcalismo en España. Estado y familia en la transición del Antiguo régimen a la Edad Contemporánea", in Casey, J. and Hernández, J. (Eds.): Familia, Parentesco y Linaje, Universidad de Murcia, Murcia, pp. 379-93.

Ferrer, L. (2011), "Acceso y distribución de los medios de producción. Herencia y reproducción social", in Chacón, F. and Bestard, J. (Eds.), Familias. Historia de la sociedad Española, Ediciones Cátedra, Madrid.

Fischer, E.M., Reuber, A.R. and Dyke, L.S. (1993), "A theoretical overview and extension of research on sex, gender, and entrepreneurship", Journal of Business Venturing, Vol. 8, pp. 151-68.

Foucault, M. (1980), "The politics of Health in the eighteenth century", in Gordon, C. (Ed.), Power/Knowledge: Selected interviews and other writings 1972-1977, Harvester Press, Brighton, pp. 166-82.

Gallhofer, S. (1998), "The silences of mainstream feminist accounting research", Critical Perspectives on Accounting, Vol. 9, pp. 355-75.

García-Baquero, A. (1972), Comercio colonial y guerras revolucionarias: la decadencia económica de Cádiz a raíz de la emancipación americana, Escuela de Estudios HispanoAmericanos, Sevilla.

Goody, J. (1983), The development of the family and marriage in Europe, Cambridge University Press, Cambridge. The translated edition has been used: Goody, J. (1986), La evolución de la familia y del matrimonio en Europa, Editorial Herder, S.A., Barcelona.

Grey, C. (1994), "Career as a project of the self and labour process discipline", Sociology, Vol. 28, No. 2, pp. 479-97.

Hammond, T. (1997), "Culture and gender in accounting research: going beyond Mynatt et al.”, Critical Perspectives on Accounting, Vol. 8, pp. 685-92.

Hammond, T. and Oakes, L.S. (1992), "Some feminisms and their implications for accounting practice ", Accounting, Auditing \& Accountability Journal, Vol. 5 No. 3, pp. $52-70$.

Hammond, T. and Preston, A. (1992), "Culture, gender and corporate control: Japan as 'Other'", Accounting, Organizations and Society, Vol. 17 No. 8, pp. 795-808.

Hanna, M. (2003), "A republic of letters: the epistolary tradition in France during World War I”, The American Historical Review, Vol. 108 No. 5, pp. 1338-61.

Haynes, K. (2008), “Moving the gender agenda or stirring chicken's entrails? Where next for feminist methodologies in accounting?", Accounting, Auditing \& Accountability Journal, Vol. 21 No. 4, pp. 539-55.

Hines, R.D. (1992), "Accounting: filling the negative space", Accounting, Organizations and Society, Vol. 17 No. 3/4, pp. 313-41.

Hopkins, E. (1986), "The trading and service sectors of the Birminghan economy (17501800)", Business History, Vol. 28 No. 3, pp. 77-97.

Hopwood, A.G. (1994), "Accounting and everyday life: an introduction", Accounting, Organizations and Society, Vol. 19 No. 3, pp. 299-301. 
Instrucción para que las Justicias de estos Reynos procedan en los varios casos y ocurrencias, que pueden sobrevenir en el embargo y seqüestro de bienes ocupados á los individuos Franceses, enacted in Sevilla, March $28^{\text {th }} 1809$.

Irigoyen, A. (2011), "Estado, Iglesia y familia: la complejidad de los cambios legislativos y socioculturales", in Chacón, F. and Bestard, J. (Eds.), Familias: Historia de la sociedad española (del final de la Edad Media a nuestros días), Cátedra, Madrid, pp. 515-604.

Jackson, W.J., Paterson, A.S., Pong, C-K.M. and Scarparo, S. (2012), “'How easy can the barley brie'. Drinking culture and accounting failure at the end of the nineteenth century in Britain", Accounting, Auditing \& Accountability Journal, Vol. 25 No. 4, pp. 635-658.

Jeacle, I. (2009), “Accounting and everyday life: towards a cultural context for accounting research", Qualitative Research in Accounting \& Management, Vol. 6 No. 3, pp. 120-36.

Kim, S.N. (2004), "Racialized gendering of the accountancy profession: toward an understanding of Chinese women's experiences in accountancy in New Zealand", Critical Perspectives on Accounting, Vol. 15, pp. 400-27.

Kim, S.N. (2008), "Whose voice is it anyway? Rethinking the oral history method in accounting research on race, ethnicity and gender", Critical Perspectives on Accounting, Vol. 19, pp. 1346-69.

Kirkham, L.M. and Loft, A. (1993), "Gender and the construction of the professional accountant", Accounting, Organizations and Society, Vol. 19 No. 6, pp. 507-58.

Kirkham L.M. and Loft, A. (2001), "The lady and the accounts: missing from Accounting History?", Accounting Historians Journal, Vol. 28 No. 1, pp. 67-90.

Komori, N. (2007), "The 'hidden' history of accounting in Japan: a historical examination of the relationship between Japanese women and accounting”, Accounting History, Vol. 12 No. 3, pp. 329-58.

Komori, N. (2008), "Towards the feminization of accounting practice: lessons from the experiences of Japanese women in the accounting profession", Accounting, Auditing \& Accountability Journal, Vol. 21 No. 4, pp. 507-38.

Komori, N. (2012), "Visualizing the negative space: making feminine accounting practices visible by reference to Japanese women's household accounting practices", Critical Perspectives on Accounting, Vol. 23, pp. 451-67.

Komori, N. and Humphrey, C. (2000), "From an envelope to a dream note and a computer: The award-winning experiences of post-war Japanese household accounting practices", Accounting, Auditing \& Accountability Journal, Vol. 13 No. 4, pp. 450-74.

Lavrin, A. and Couturier, E. (1979), "Dowries and wills: a view of women's socioeconomic roles in colonial Guadalajara and Puebla, 1640-1790", Hispanic American Historical Review, Vol. 59 No. 2, pp. 280-304.

Lehman, C. (2012), "We've come a long way! Maybe! Re-imagining gender and accounting", Accounting, Auditing \& Accountability Journal, Vol. 25 No. 2, pp. 256-94. 
Llewellyn, S. and Walker, S.P. (2000), "Household accounting as an interface activity: the home, the economy and gender", Critical Perspectives on Accounting, Vol. 11 No. 4, pp. 447-78.

Lario, M.C. (2000): La colonia mercantil británica e irlandesa en Cádiz a finales del siglo XVIII, Servicio de publicaciones de la Universidad de Cádiz.

López-Cordón, M.V. (1982), "La situación de la mujer a finales del Antiguo Régimen”, in R.M. Capel (Ed.), Mujer y sociedad en España (1700-1975), Ministerio de Cultura, Madrid, pp. 47-107.

Merino, B.D. and Mayper, A.G. (1993), "Accounting history and empirical research", The Accounting Historians Journal, Vol. 20 No. 2, pp. 237-267.

Napier, C.J. (2006), "Accounts of change: 30 years of historical accounting research", Accounting, Organizations and Society, Vol. 31 No. 4/5, pp. 445-507.

Oakes, L.S. and Young, J.J. (2008), "Accountability re-examined: evidence from Hull House", Accounting, Auditing \& Accountability Journal, Vol. 21 No. 6, pp. 765-90.

Ortega, M. (1997), "Las mujeres en la España Moderna", in Garrido, E. (Ed.), Historia de las mujeres en España, Editorial Síntesis, Madrid, pp. 249-414.

Ortego, M.A. (1999), Familia y matrimonio en la España del siglo XVIII: Ordenamiento jurídico y situación real de las mujeres a través de la documentación notarial, Unpublished Ph.D, Departamento de Historia Moderna, Universidad Complutense de Madrid.

Panayiotou, A. (2015), "Spacing gender, gendering space: a radical 'strong plot' in film", Management Learning, Vol. 46 No. 4, pp. 427-43.

Parker, L.D. (2008), "Strategic management and accounting processes: acknowledging gender", Accounting, Auditing \& Accountability Journal, Vol. 21 No. 4, pp. 611-31.

Pérez, I., Vicente, M., Ibero, A., Carrasco, E. and Gil, A. (1994), Las mujeres en el Antiguo régimen. Imagen y realidad (siglos XVI-XVIII), ICARIA Editorial, Barcelona.

Roberts, J. and Coutts, J.A. (1992), "Feminization and professionalization: a review of an emerging literature of the development of accounting in the United Kingdom", Accounting, Organizations and Society, Vol. 17 No. 3/4, pp. 379-95.

Soria, E. (2007), La nobleza en la España moderna. Cambio y continuidad, Marcial Pons Ediciones de Historia, Madrid.

Thane, P. (1992), "The history of the gender division of labour in Britain: Reflections on "Herstory' in accounting: The first eighty years", Accounting, Organizations and Society, Vol. 17 No. 3/4, pp. 299-312.

Tyler, M. and Cohen, L (2010), "Spaces that matter: gender performativity and organizational space”, Organization Studies, Vol. 31 No. 2, pp. 175-98.

Vickery, A. (2006), "His and Hers: gender, consumption and household accounting in Eighteenth-Century England", Past and Present, Vol. 1 (suppl 1), pp. 12-38.

Virtanen, A. (2009), “Accounting, gender and history: the life of Minna Canth", Accounting History, Vol. 14 No. 1/2, pp. 79-100. 
Vogler, C. and Pahl, J. (1994), "Money, power and inequality within marriage", The Sociological Review, Vol. 42 No. 2, pp. 262-88.

Walker, S.P. (1998), "How to secure your husband's esteem. Accounting and private patriarchy in the British middle class household during the nineteenth century", Accounting, Organizations and Society, Vol. 23 No. 5/6, pp. 485-514.

Walker, S.P. (2003), "Professionalisation or incarceration? Household engineering, accounting and the domestic ideal", Accounting, Organizations and Society, Vol. 28, pp. $743-72$.

Walker, S.P. (2006), "Philanthropic women and accounting. Octavia Hill and the exercise of 'quiet power and sympathy'", Accounting, Business and Financial History, Vol. 16 No. 2, pp. 163-94.

Walker, S.P. (2008), “Accounting histories of women: beyond recovery?", Accounting, Auditing \& Accountability Journal, Vol. 21 No. 4, pp. 580-610.

Walker, S.P. and Carnegie, G.D. (2007), "Budgetary earmarking and the control of the extravagant woman in Australia, 1850-1920", Critical Perspectives on Accounting, Vol. 18 , pp. 233-61.

Walker, S.P. and Llewellyn, S. (2000), "Accounting at home: some interdisciplinary perspectives", Accounting, Auditing \& Accountability Journal, Vol. 13 No. 4, pp. 42549.

Wiskin, C. (2006), "Businesswomen and financial management: three eighteenth-century case studies", Accounting, Business and Financial History, Vol. 16 No. 2, pp. 143-61. 